\title{
Rothmans' free fall into the abyss of bad taste
}

The siege mentality can cause those in the bunker to act very foolishly. There have been few better examples of this than the antics of Rothmans of Pall Mall in Australia during 1995. With its two competitors in the Australian industry, WD \& HO Wills (BAT) and Philip Morris, Rothmans has been wincing badly from the triple whammy of bold new pack warnings, ${ }^{1}$ an all-but-total advertising ban (point-of-sale exempted), and having been aggressively spurned in the tobacco control policies of all three major political parties. With its back to the wall, Rothmans has embarked on what it probably imagined would be a glorious fightback.

At the bridge of its campaign is a new brand, Freedom, launched on 30 April 1995 in the red and black livery traditionally associated with the anarchist movement. With timing as crass as it was naive, in the same week Rothmans also embarked on an advocacy campaign for smokers' rights. The much hyped "campaign" features the talents of Richard Farmer, a political lobbyist, and one large billboard in each of several Australian cities proclaiming "Personal liberty is the right of every Australian". Traditionally tobacco companies have eschewed media interviews and debates, but Farmer has been willing to be interviewed across the country.

Farmer freely admits to being a heavy smoker. His gnarled visage and raspy voice have been pilloried by journalists and the public alike as he utters the standard industry lines about government having gone too far, prohibition, anti-smoking zealots, standing up for smokers, and the slippery slope into other advertising bans.

ABC-TV's national coverage of the campaign launch showed an unedited Farmer coughing and spluttering off camera before faltering in part of his interview, causing the TV journalist to comment that "he was still practising his lines". A subsequent blustering op-ed page contribution in the Sydney Morning Herald was accompanied by his photograph, causing a letter-to-the-editor writer to reply that he was "Rothmans' best advertisement yet - the endearing wrinkling of that subtly greying skin, that little lung-mucker lovingly in hand, the haunted, hunted, hypoxic look in your eyes. Get 'em to print one of your chest $x$ rays next time."

Those working in tobacco control in Australia relish the thought of Farmer's continuing involvement with Rothmans. His selection may say much about the dearth of individuals willing to do the tobacco industry's bidding.

Besides the "I am the face of Australian smoking" message Farmer sends to the Australian public, Rothmans have kicked four monumental own goals against their industry with the Freedom launch.

- The "coincidence" of the launch of a brand and a conceptually similar advocacy campaign in the same week fooled no one. By using advocacy advertising in this way, Rothmans will be judged as seeking to undermine the Government's tobacco advertising ban. This seems certain to irritate Government officials and politicians further and may lead to additional fine-tuning of the controls on tobacco industry communication.

- By attaching a pull-out leaflet inside the packs (see figure), Rothmans have shown that such a packaging innovation is possible, thus spoiling any future argument they might wish to mount against health advocates' arguments that pack inserts could be made mandatory so that all additives could be listed.

- In placing a message across two thirds of the
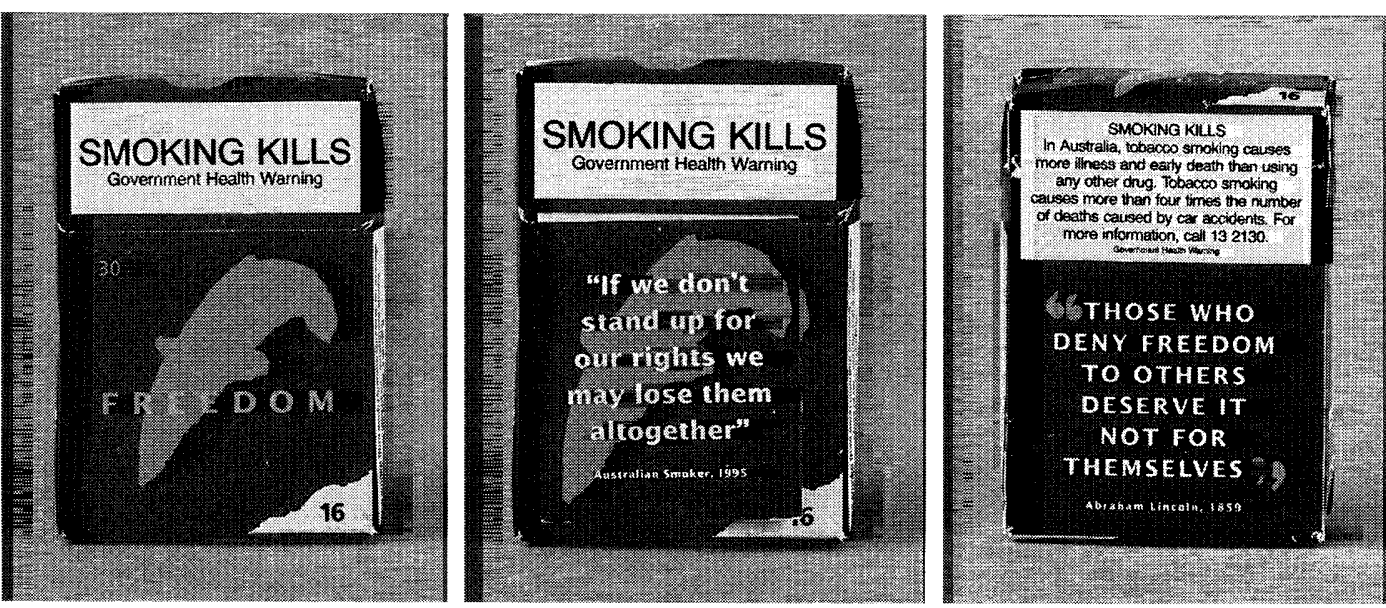

Rothmans' Freedom cigarettes: front of the pack (left), the pull-out leaflet (middle), and the back of the pack (right). 
back of the pack (see figure), they have shown - contrary to their previous protestations that it is possible to fill this space with information without jeopardising its mysterious and often vaunted integrity in the matter of "branding".

- And perhaps most significantly, by having the temerity to name a brand "Freedom" and to use a statement made by Abraham Lincoln in a context of condemning the slavery of African Americans, it has displayed a degree of arrogant petulance and appalling offensiveness that has further outraged key legislators in Australia. Federal Health Minister Dr Carmen Lawrence publicly described Freedom as "a very sick joke given the number of people who are slaves to tobacco". 3

Philadelphia's African American tobacco control advocate Reverend Jesse Brown, alerted to the Lincoln quote by an Australian advocate, has already condemned Rothmans on Sydney radio for its gross offensiveness to African Americans. As we go to press, Brown is in the process of launching an official complaint to both Rothmans and the Australian Embassy in Washington, DC. With Australia's ultrasensitivity over racial matters because of its historical treatment of its Aboriginal population, Rothmans face serious humiliation.

In the March 1995 State elections in New South Wales, a newly emerged Smokers' Rights Party managed to attract some 32000 votes-less than half of one percent of all formal votes cast. Despite this pathetic showing, Farmer and Rothmans continue to blather about "clear evidence of a backlash against the social engineering of the neo-prohibitionists of the anti-smoking movement" and sabre rattling to politicians that they "realise that the seeds are there for the anger of voters to affect the way they vote." 4

On the contrary, the seeds that seem most likely to sprout in the near future are the departure from the Australian market of at least one tobacco company (Wills recently reported a record profit loss and is rumoured to be at the mercy of takeover bids); the rapid wind-down of what remains of the local growing industry following the planned removal of all government subsidies; and a drop in smoking prevalence to below $20 \%$ by the year 2000

As Janis Joplin sang in the 1970s, "Freedom's just another word for nothing left to lose". Rothmans' performance with its Freedom brand way well be seen by tobacco control historians as a last ditch, almost kamikaze mission by a desperate industry.

SIMON CHAPMAN

Deputy Editor

1 Chapman S. Tobacco down again, down under. Tobacco Control 1995; 4: 17-8.

2 Kennedy J. Tobacco industry's spurious arguments [letter]. Sydney Morning Herald 1995; 24 July: 12.

3 Australian Associated Press. Lawrence signals tougher action on tobacco ads. Press release. Canberra, 30 May

4 Polgaze K. Cigarette company launches smokers' rights campaign. Australian Associated Press 1995, April 30.

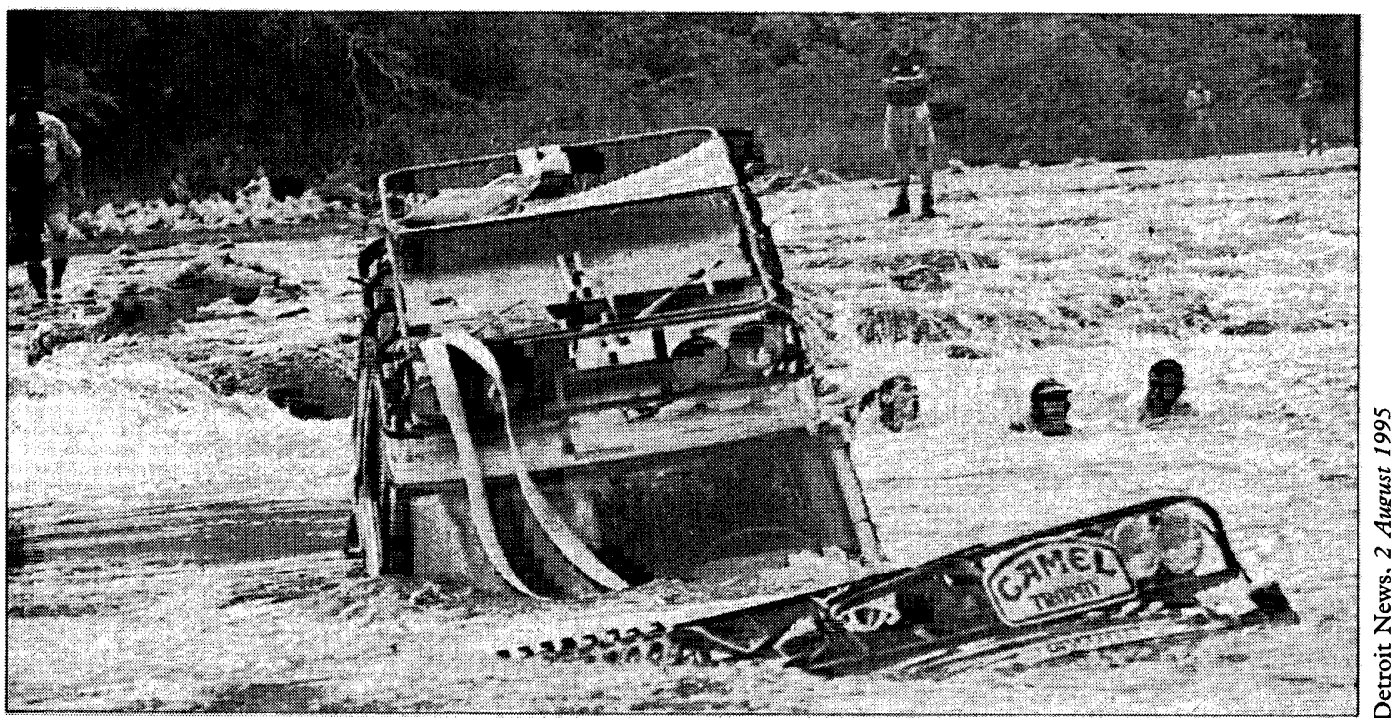

A Land Rover Discover wagon fords the Mopan River in Belize during the 1995 Camel Trophy Challenge. Camel Trophy teams from 24 countries participated in this 1,050-mile $(1,680-\mathrm{km})$ "exhibition through the

Mayan World of Central America", described by the Detroit News (2 August 1995) as the "ultimate

challenge in the world of four-wheel-drive vehicles". 